DOI: http://doi.org/10.4038/ss.v49i2.4719

\title{
Determinants of Microfinance Interest Rates: Case of Sri Lanka
}

\author{
Indeewari U. Colombage and Tharanga A.D. Wijayakoon ${ }^{2}$
}

\begin{abstract}
This research attempts to identify determinants of microfinance interest rates with a view to control and reduce such rates for the betterment of microfinance clients. Data from 30 microfinance institutions were gathered using a set format to capture required variables. The variables covered the cost of funds, efficiency, competition and company characteristics. Variables such as return on assets, non-performing accommodations, competition and average loan size were considered as endogenous. Therefore, a two stage least square panel regression using random effects was used to analyse the data. The identified determinants of microfinance interest rates were the prior period's interest rate, cost of funds, efficiency, the size of firm and profitability. However, competition, the nature of microfinance institution and the experience of the firm did not give significant results. Accordingly, it is recommended that appropriate action should be taken to reduce the cost of funds, improve efficiency and transmit the profitability of institutions to the microfinance client. Further, policies should be developed to improve transparency in the pricing imposed by such institutions and to enhance financial literacy of the public to derive benefits of competition. Thereby, the size of firm, experience and regulatory position can be stimulated to minimize interest rates.
\end{abstract}

Key Words: Competition, Cost of Funds, Efficiency, Microfinance Institutions, Interest Rates

${ }^{1}$ The author is currently serving as a Senior Assistant Director of the Department of Macroprudential Surveillance at the Central Bank of Sri Lanka. Corresponding email: indeewari@cbsl.lk

${ }^{2}$ The author is currently serving as a Senior Assistant Director of the Department of Supervision of Non-Bank Financial Institutions at the Central Bank of Sri Lanka. Corresponding email: tharangaw@cbsl..k. authors are thankful to the anonymous reviewers for their comments and advice. The views presented in this paper are those of the authors and do not necessarily indicate the views of the Central Bank of Sri Lanka. 


\section{Introduction}

Microfinance is defined by the Consultative Group to Assist the Poor (CGAP) as "provision of financial services to low-income people”, CGAP (2017). This could include provision of credit, savings facilities, insurance and pension products, money transfer services, and training and consultation services. Banks have traditionally considered low-income persons as 'unbankable' as they have no conventional collateral to offer and micro-enterprises operated by such persons are rather small and risky. Microfinance Institutions (MFIs) provide access to finance for such individuals. However the role of microfinance extends beyond simply providing access to finance and thereby increasing financial inclusion. MFIs empower their clients by providing various training and development opportunities (Zerai \& Rani 2011), to better utilize their finances. Microfinance, through employment generation empowers clients, helps reduce poverty, and helps reduce inequality in wealth distribution (Cotler \& Almazan 2013).

In the 1970s, MFIs required substantial subsidies to serve their clients (Morduch et al. 2009). Therefore, as Lingerwood (2001) and Xhristen (1997) note, during this period microfinance projects were entirely donor funded with limitations on funds, time, economic activity and geographical location (as cited by Kipesha \& Zhang 2013). In the 1980s and 1990s policy makers argued that MFIs should be profitable/financially sustainable (Morduch et al. 2009). It was argued that access to finance is more important than the price, and any price MFIs charge is justified, if it is below what the local money lenders charge (ibid.). According to this premise, both non-profit and for-profit MFIs were encouraged to raise interest rates. However, such high interest rates have not resulted in increased profits for MFIs (Roberts 2013). High rates of default, higher administration costs and policies of low interest rates were assumed to prevent MFIs from being profitable (Sanderatne 2007). According to Mardoch (2000) and Ottero (1999), MFIs continued to be affected by dependence on donor funds and poor fund management (as cited by Kipesha \& Zhang 2013). This resulted in an argument for more efficient and sustainable MFIs (Kipesha \& Zhang 2013). According to Christen (2001), Isern \& Porteous (2006) and Ryne (1998), a profitable MFI would be able to reach more people while being less dependent on donor funds (as cited by Kipesha \& Zhang, 2013). However, in Sri Lanka, both not-for-profit Non-Governmental organizations as well as for-profit MFIs operate parallelly.

Emphasis on financial sustainability has resulted in the number of for-profit MFIs increasing (Roberts, 2013). With the emphasis on profitability, the social objective of poverty alleviation of MFIs has moved towards the economic objective of providing sustainable and market based financial services (Zerai \& Rani 2011). According to Ledgerwood (1999) Christen (1998) and Mordich (2000), MFIs have been pressured to adopt more "business" practices and to become more self-sufficient (as cited by Zerai \& Rani, 2011). Therefore, modern MFIs are expected to meet the double objectives of alleviation of poverty, while maintaining their financial viability. 
It is a common complaint against microfinance that its interest rates are excessive (Cotler \& Almazan, 2013; Hudon 2007), which is relevant to Sri Lanka as well (news.lk 2015). Stronger for-profit orientation has been found to correspond with higher interest rates for MFI clients (Roberts, 2013). This has contributed to the problem of over-indebtedness seen in many microfinance markets (Schicks 2010), including Sri Lanka (The Sunday Times 2017). Gonzalez (2010) and Rosenberg, Gonazalez and Narain (2009) allege that high lending interest rates have led to the over-indebtedness of clients of MFIs and deviation from the essence of microfinance (as cited by Cotler and Almazon 2013), which is its social objective of poverty alleviation. It is also stated that such high interest rates are charged to obtain excessive profits. e.g. the case of Compartamos in Mexico obtaining high share prices due to profits earned through excessive interest rates (CGAP 2009).

A financial institution wishes to charge the highest lending interest rate possible, whereas the clients would prefer the lowest interest rate (Hudon 2007). Therefore, there is an inherent mismatch between these two objectives (ibid.). The role of a regulator of financial institutions would be to balance these two conflicting objectives in a way that ensures the viability and sustainability of financial institutions while reducing the burden on clients. Therefore, regulators should have a broad knowledge on determinants of lending interest rates in MFIs to effectively address this condition. Nevertheless, when considering previous literature, the findings differ according to the variables that affect lending interest rates/profits, and the correlations between variables. Moreover, the impact on interest rates from such variables has not been studied in the Sri Lankan context, even though adverse effects pertaining to exorbitant lending interest rates of MFIs are widely discussed by the public. Therefore, it is imperative to study the factors that determine the lending interest rates in the microfinance sector in Sri Lanka, in order to address the excessive interest rates problem through appropriate policy decisions. This study expects to address this issue and identify which determinants affect lending interest rates and their magnitude as well as correlations between variables, thereby enabling policy makers to identify and implement remedies to reduce lending interest rates of the microfinance sector of Sri Lanka.

\subsection{Theoretical foundation}

In modern microfinance there is a debate between the financial systems approach, which states that it is essential that MFIs be profitable, and the poverty lending approach, which states that microfinance must make subsidized credit available to the poor, irrespective of profitability (Zerai \& Rani 2011). These two types of MFIs, for-profit institutions and not-for-profit institutions, both function in the microfinance industry. Both approaches share the common goal of providing financial services to the poor, but being profitable would enable MFIs to raise capital through the capital markets and expand its operations (ibid). The poverty lending approach assumes that the poor cannot afford high interest rates (op.cit), which is confirmed by research that has found that the profit motive of MFIs is expected to have a negative 
impact on the outreach to the poor (Kipesha \& Zhang 2013). It is contended that with the profitability focus, the poorest of the poor would not be reached, due to the high cost of finance associated with servicing such clients (Sanderatne 2007). While self-sustained MFIs have become larger and more efficient, they also tend not to target the very poor, as targeting the less poor leads to increases in loan size and improves efficiency indicators (Kipesha \& Zhang 2013).

Contrary to the above views, some research shows that profitability has a positive correlation with outreach (Kipesha \& Zhang 2013). It is claimed that empirical evidence neither shows that the poor cannot afford higher interest rates, nor that there is a negative correlation between the financial sustainability of the institutions and the poverty level of the clients (Zerai \& Rani 2011). Sanderatne (2007) states that microfinance clients pay much higher rates to informal lenders, who are their only substitute to finance provided by MFIs. Therefore, Sanderatne (2007) contends that MFIs can afford to offer much higher rates than those offered by commercial banks to their clients. Further, Adam, Graham and Von Pischke (1984) contend that empirical evidence has shown that subsidized lending has led to low repayment rates, a large number of unintended beneficiaries, and funds not being used for intended purpose (as cited by Sanderatne 2007). Low interest rates have a disadvantage for mobilisation of savings, since the savings deposits rate has to be lower than the onlending rate. An MFI which gives credit at a low rate would be offering a low savings deposit rate as well, which would reduce its capacity to mobilize deposits. There is evidence to suggest that when a credit organisation disburses cheap credit, the borrowers perceive the credit to be a grant or a gift rather than a repayable loan (Sanderatne 2007). Therefore, it is clear that there is more weight for the adoption of the financial systems approach. In fact, regulators have recognized this approach by encouraging non-governmental organisations, which are not-for-profit organisations, to convert themselves into for-profit shareholderowned companies, and to accept public deposits (CGAP brief). The Microfinance Act, No.6 of 2016 of Sri Lanka, also provides that applicants for licence under the Act must be public companies.

Woller (2000) asserts that the only way MFIs can adopt the financial systems approach and be sustainable while serving the poor, is by charging high enough interest rates to increase their income or by lowering their costs (as cited by Zerai \& Rani 2011).

For an MFI, the main source of income is the interest income (Sandaratne 2007). Further, the interest paid to deposits mobilized by an MFI and the profitability margin of the MFI depend on the interest charged from lending to its clients. It is also argued that high interest margins reflect low efficiency, non-competitive market conditions, inadequate regulatory environments and a high degree of information asymmetry (Clayes \&Vannet 2008). For an MFI to become profitable, the lending interest rate should reflect the cost of funds, administration cost, transaction cost and loan loss provisioning (Sandaratne 2007). However, in addition to interest rates, the operational and administrative efficiency of an MFI is also important in determining 
its profitability (ibid). Effectively, for an MFI which is focused on profitability, it is the costs that should determine the realistic rate of interest it should charge (op. cit). Especially, in the case of microfinance, costs are higher compared to other financial institutions, due to the high administration cost of small loans, higher operational cost due to higher cost of accessibility of clients, and close monitoring of loans and the higher risk of default. However, all these costs can be reduced over time by improved practices, higher accountability of borrowers, improved information and reduced moral hazard, and improved operational efficiency. Therefore, in the long run, MFIs should attempt to cut their margins and their rates of interest, while maintaining profitability. At the same time, curtailment of expenditure by paying low salaries and recruiting poor quality staff might lead to an increase in costs due to inefficiency in operations. Therefore, it can be expected that in addition to profit margin, cost of funds and operational and administrative efficiency have an impact on the lending interest rates of an MFI.

In Creating a World without Poverty (2007), Mohamed Yunus has proposed a methodology for the evaluation of microcredit interest rates (Gonzalez 2010). The proposed methodology is based on calculating the interest rate premium, defined as the interest rate charged by the MFI and the cost of funds, at the market rate paid by the MFI (ibid). As per the methodology, if the premium is more than 15, the MFI is in the red zone, and is considered to be "profit maximizing". Lower premiums are categorized into Yellow and Green zones. Gonzalez (2010) analyses global MFIs using this methodology and comes to the conclusion that three out of four MFIs worldwide fall into the 'red zone'. As per Gonzalez (2010), the categorization can almost entirely be explained by operating expenses and loan sizes. There is no evidence that institutions in any of the zones are taking supernormal profits. In fact, the research reveals that even if the MFIs lowered their lending rates to a level which would make their profits zero, $61 \%$ of the institutions would still be in the red zone, compared to the actual figure of $75 \%$, which is not a significant improvement. Therefore, it would be worth studying research that focuses on factors that determine the profitability of financial institutions (Gonzalez (2010). However, Rosenberg et al. (2009) state that even an interest rate which only covers the operational cost of MFIs without any profits can still be unreasonable if the costs are excessively high because of avoidable inefficiencies. Therefore, when studying the factors affecting interest rates, one may study the effects on lending interest rates rather than profits.

Further, regulators have adopted the method of imposing an interest rate cap as a solution for excessive interest rates. Interest rate caps are expected to reduce the debt burden of microfinance clients and can be used as an effective means of microfinance client protection. According to Maimbo and Gallegos (2014), 76 countries around the world use some sort of interest rate caps on loans. However, many writers agree that interest rate caps are detrimental to the microfinance industry. Maimbo and Gallegos (2014), CGAP (2004) and Fernando (2006), contend that interest rate caps lead to MFIs withdrawing from poorer segments of the market, while the increase of total cost of loans due to additional fees and 
commissions makes it hard for new MFIs to emerge, reduces growth of MFIs, becomes less transparent about loan charges, discourages potential investors in the industry, reduces creditworthiness of MFIs-resulting in a decline in supply of credit to the industry, creates an artificially high demand from microfinance credit, and lowers deposit interest rates for microfinance clients.

\section{Literature review}

Researchers have found a number of factors, both internal and external to MFIs, to be determinants of interest rates charged by MFIs. Hudon (2007) finds that competition is a main factor in determining interest rates. Cotler and Almazon (2013), studying MFIs in a number of countries, identify that funding costs, loan size and efficiency levels affect interest rates of MFIs. They find that while funding costs have a positive relationship, loan size and efficiency have a negative relationship with lending interest rates. Cotler and Almazon (2013) also detect a negative correlation between competition and interest rates only in Asia. Similarly, Fehmeen (2010) states that cost of funds, operating costs, provision for bad debts, tax expenses, credit rating of clients, profit, inflation, competition and financial literacy of clients are the determinants of interest rates. Rosenberg (2002) proposes that administrative expenses, loan losses, cost of funds, the desired capitalization rate and investment income determine the interest rate of an MFI. Gonzalez (2010) states that operating costs almost entirely explain the interest rates of MFIs. Petersen and Rajan (1995) finds that as market power increases, interest rates decline. Sandaratne (2013) argues that operational efficiency and cost of funds have an influence on interest rates.

Boot and Thakor (2000) claim that intense competition may prompt financial firms to reallocate resources to more relationship lending, resulting in smaller firms facing a reduction in interest rates. Contrary to Petersen and Rajan (1995), Boot and Thakor (2000) find that as market power increases interest rates increase. With similar findings, Marquez (2002) and McIntosh \& Wydick (2005) argue that as competition among financial institutions increase, interest rates follow a similar path.

Carbo-Valverde et al. (2009) show that the correlation between competition and interest rates is sensitive to how market power is assessed. If market power is supported by the Lerner Index, the results support the conventional theory that greater market power implies higher interest rates. However, if market power is defined by concentration indexes, the results are the opposite, and the conventional theory is discarded.

Rosenberg et al. (2009) find that interest rates are not affected by unreasonable loan losses. It is further stated that profits are not a predominant driver of interest rates. For the median MFI, in the unlikely scenario of complete elimination of all profits, the interest rate would drop only by one-seventh. Rosenberg et al. (2009) also find that interest rates reduced in markets where microcredit has become competitive, except in the case of Bangladesh. 
Cull et al. (2006) examine the determinants of profitability, portfolio at risk and loan size in the microfinance sector without taking into account how much competition lenders face because the typical proxies for measure of competition have endogeneity problems and do not measure how intense the competition is. They find that lending interest rates and capital costs affect the profitability of financial institutions. Zerai and Rani (2011), in relation to MFIs in India, find that empirical evidence does not support a tradeoff between outreach and financial sustainability.

Gonzalez and Rosenberg (2009) find that profitable MFIs grow much faster than unprofitable ones but growth is not linked to profitability, at least while the MFI is in its early years and maintains a modest level of clientele. They further find that the correlation between the loan size and profitability is very weak, and interest rates and spreads drive profitability more than costs or productivity do. Gonzalez and Rosenberg (2004) also found that scale (number of borrowers or assets' size) does not help explain profitability. They conclude that there is little conflict between improving sustainability and reaching poor clients.

Dissanayake (2012) determines that cost per borrower and debt/equity ratio are statistically significant in determining the profitability of an MFI. He finds a negative relationship between operating expenses and profitability, and finds that cost per borrower and write-offs positively affect profitability.

Kipesha and Zhang (2013), in relation to 47 MFIs in 47 African countries, find a negative significant correlation between outreach and profitability. Kipesha and Zhang (2013), further find that the existence of tradeoffs between financial performance and outreach to the poor depend on the variables used and estimation model specifications.

\section{Methodology}

The study was carried out using data obtained from members of the Lanka Microfinance Practitioners Association, out of which 30 MFIs responded to the request to answer a questionnaire provided by the authors. Therefore, convenience sampling ${ }^{1}$ has been used to obtain the sample for this study. Further, in order to obtain reliable data, the questionnaire was to be completed using audited data. The time span considered for the study was from 2005 to 2017. Majority of these MFIs were not in operation or had not formulated audited accounts before 2005. Therefore, data beyond this year were not sought for the research. As certain institutions have not been in operation since 2005, an unbalanced panel dataset was compiled. Altogether the sample comprised 199 data points.

\footnotetext{
${ }^{1}$ At present, MFIs are not supposed to report their financial details to a regulatory body. Therefore, it is difficult to obtain reliable data from MFIs. As such, data accumulation was done with the support of the Lanka Microfinance Practitioners Association which most MFIs are members of. However, only 30 MFIs responded to the questionnaire, despite consistent reminders.
} 
In order to identify the determinants of interest rates, market experience gathered from various previous studies were used. Cotler and Almazon (2013), Rosenberg (2002), Fehmeen (2010), Rosenburg et al. (2009) and Gonzalez (2010) give an insight into identifying the data requirement for this study. Cotler and Almazon (2013) and Gonzalez (2010) have obtained secondary data from the Microfinance Information Exchange ${ }^{2}$ database. The data for this study was obtained by circulating a format that comprise financial components which were used to derive the required variables (the format used to collect data is given in Appendices Table A1.

A regression analysis was used to analyze the data. The lending rate was considered to be the dependent variable with the determinants as the independent variables. The lending interest rate can be identified according to two methods. i.e. weighted average interest rates, which is obtained through the rates actually charged by the MFIs, or the portfolio yield, which can be a proxy for interest rates (Gonzalez, 2010). The portfolio yield is calculated by dividing the interest by the average gross loan portfolio (Cotler \& Almazon 2013; Gonzalez 2010). If the weighted average interest can be reliably obtained, it is a more precise measure of the interest rates. However, it is difficult to obtain this rate from MFIs as it involves a complex calculation using numerous products offered by such institutions. Further, requesting such data will give a clear indication of the interest rates, which such institutions are reluctant to disclose, and thereby tend to underestimate. Furthermore, the main positive impact of obtaining the portfolio yield is that it captures the effective interest rate.

Independent variables, which are the possible determinants of interest rates, are funding costs, indicators of efficiency, characteristics of the MFI, market power and economic environment (Cotler \& Almazon 2013). Proxies for cost of funds, market power and characteristics of the MFI and efficiency are considered as the independent variables in this study. Cost of funds is derived through interest expenses and clients are considered as market power for this particular sample by identifying the number of borrowers as a percentage of total borrowers of the sample for that particular time period. Operating expenses as a percentage of loan portfolio, non-performing accommodation and average loan size are used to account for the efficiency. Characteristics of an MFI such as its experience measured through number of years in operation, size of the firm measured through total assets, profitability measured through return on assets and nature of the firm are used. The question whether regulated MFIs charge higher interest rates compared to other MFIs is captured by segregating the nature of institutions appropriately. The derivation of all variables is given at Table 1.

\footnotetext{
${ }^{2}$ Microfinance Information Exchange is "an online platform that allows users to assess market conditions, individual Financial Service Providers' performance, and the financial inclusion landscape.”
} 
Table 1: Derivation of Variables

\begin{tabular}{|c|c|}
\hline Variable & Derivation of the variable \\
\hline Lending interest rate & Interest Income divided by loan portfolio and multiply by 100 \\
\hline Cost of Funds & Interest expenses divided by loan portfolio and multiply by100 \\
\hline Non-Performing Accommodations & $\begin{array}{l}\text { The non-performing accommodations as a percentage of total loan } \\
\text { portfolio of the microfinance institution }\end{array}$ \\
\hline Average loan size & Total loan portfolio divided by the number of loans \\
\hline Operational efficiency & Operational expenses as a percentage of total loan portfolio \\
\hline Return on Assets & Profit as a percentage of total assets \\
\hline Outreach & Number of branches of the microfinance institution \\
\hline Provision percentage & Provisions/impairment as a percentage of total assets \\
\hline Age & $\begin{array}{l}\text { Number of years the microfinance institution has been conducting } \\
\text { microfinance }\end{array}$ \\
\hline Market Power & $\begin{array}{l}\text { Number of borrowers in a particular microfinance institution as a } \\
\text { percentage of the total number of borrowers of the sample microfinance } \\
\text { institutions }\end{array}$ \\
\hline Size of firm & The natural log of total assets of the microfinance institution \\
\hline \multirow[t]{2}{*}{ Nature of firm } & If the microfinance institution is a finance company $=1$ \\
\hline & $\begin{array}{l}\text { If the microfinance institution is an institution other than a finance } \\
\text { company }=0\end{array}$ \\
\hline
\end{tabular}

\subsection{Hypotheses}

\section{Cost of Funds}

H1 - Lending interest rates will be indifferent on cost of funds of the microfinance institution

Efficiency

H2 - Lending interest rates will be indifferent on Non-performing accommodation Rate

H3 - Lending interest rates will be indifferent on average loan size

H4 - Lending interest rates will be indifferent on operating expenses Competition

H5 - Lending interest rates will be indifferent on competition Company Characteristics

H6 - Lending interest rates will be indifferent on experience of the microfinance institution

H7 - Lending interest rates will be indifferent on profitability

H8 - Lending interest rates will be indifferent on size of microfinance institution

H9 - Lending interest rates will be indifferent on nature of microfinance institution

However, it is observed that there may be variables that can be considered as independent, depending on interest rates and other variables. Return on assets, average loan size, market power and non-performing accommodations can be considered to be such variables.

Return on assets and average loan size are dependent upon profitability goals, and interest rates determine the profitability goals of any institution (Cotler \& Almazon 2013, Cull et al. 
2006). Cotler and Almazon (2013) further state that the average loan size is dependent upon efficiency, experience of the company, market power and lending interest rates. Return on assets is dependent upon efficiency, outreach, cost of funds, lending interest rates and provisions.

Market power is another possible endogenous variable. One of the main criteria that have to be considered by a borrower is the interest rate the microfinance institution offers. Therefore, the number of borrowers attracted to a particular microfinance institution, which indicates the market power, may be dependent on the interest rate.

Non-performing accommodations may also be dependent on interest rates. When interest rates are high, borrowers will have to pay higher installments. When installment sizes are high, it is apparent that propensity to default a loan is high. Therefore, non-performing advances may change depending on the interest rates.

Regression equations to derive Return on Assets, Average Loan Size, Market Power and Non-Performing Accommodations are as follows:

$$
\begin{aligned}
& \mathrm{R}=\mathrm{b}+\mathrm{y} Y+\mathrm{cC}+\mathrm{eE}+\mathrm{oO}+\mathrm{pP} \\
& \mathrm{L}=\mathrm{d}+\mathrm{yY}+\mathrm{cC}+\mathrm{eE}+\mathrm{aA}+\mathrm{mM} \\
& \mathrm{M}=\mathrm{e}+\mathrm{yY}+\mathrm{cC}+\mathrm{oO} \\
& \mathrm{N}=\mathrm{f}+\mathrm{yY}+\mathrm{eE}+\mathrm{oO}+\mathrm{mM}
\end{aligned}
$$

As this is a panel dataset that contains endogenous variables the two stage least square technique (2SLS) was used. The econometric package e-views was used to analyze the data. The reduced form equation for the endogenous variables was obtained and an ordinary least square regression was carried out. The fitted values were obtained for such regressions and a panel data regression with random effects was carried out on various combinations to obtain the final results. The random effect used as the sample was obtained randomly, and the fixed effect could not be used as the nature of the MFI is used as the time constant variable. The instrumental variables used in this 2SLS regression are the predicted values of the endogenous variables.

\section{Results and discussion}

\subsection{Descriptive statistics}

The descriptive statistics of all the variables under consideration are given in Table 2. The highest interest rate reported is $107.79 \%$, which indicates that there are instances where borrowers pay twice as much the amount they have borrowed. Further, there are instances where the rate has only been $2 \%$, which is from a not-for-profit organization. The cost of funds has been zero in a not-for-profit organization whereas the highest has been $37 \%$. The details of other variables are as follows: 
Table 2: Descriptive Statistics of the Variables

\begin{tabular}{lcccccc}
\hline \hline Item & Experience & $\begin{array}{c}\text { Average } \\
\text { Loan Size }\end{array}$ & $\begin{array}{c}\text { Cost of } \\
\text { Funds }\end{array}$ & $\begin{array}{c}\text { Market } \\
\text { Power }\end{array}$ & $\begin{array}{c}\text { Interest } \\
\text { Rates }\end{array}$ & $\begin{array}{c}\text { Log Total } \\
\text { Assets }\end{array}$ \\
\hline Mean & 10.86 & $97,325.05$ & 6.76 & 5.78 & 27.44 & 19.75 \\
Median & 10.00 & $37,163.68$ & 5.88 & 1.13 & 25.06 & 19.54 \\
Maximum & 42.00 & $838,712.50$ & 37.07 & 100.00 & 107.79 & 25.16 \\
Minimum & 1.00 & 482.00 & - & 0.01 & 2.00 & 14.95 \\
Std. Dev. & 8.37 & $169,382.70$ & 6.47 & 14.84 & 14.06 & 2.15 \\
Skewness & 2.71 & 3.14 & 2.01 & 4.50 & 2.38 & 0.37 \\
Kurtosis & 10.87 & 12.38 & 8.74 & 24.23 & 12.53 & 2.78 \\
Observations & 199 & 199 & 199 & 199 & 199 & 199 \\
\hline
\end{tabular}

\begin{tabular}{lcccccc}
\hline \hline Item & $\begin{array}{c}\text { Nature of } \\
\text { Company }\end{array}$ & $\begin{array}{c}\text { Operational } \\
\text { Expenses }\end{array}$ & $\begin{array}{c}\text { Non- } \\
\text { Performing } \\
\text { Assets }\end{array}$ & Outreach & Provision \% & $\begin{array}{c}\text { Return on } \\
\text { Assets }\end{array}$ \\
\hline Mean & 0.24 & 20.78 & 5.38 & 27.73 & 2.20 & 0.52 \\
Median & - & 17.70 & 3.00 & 13.00 & 0.75 & 1.68 \\
Maximum & 1.00 & 87.77 & 94.59 & 158.00 & 56.57 & 20.96 \\
Minimum & - & $(0.68)$ & - & - & $(8.50)$ & $(71.67)$ \\
Std. Dev. & 0.43 & 13.92 & 9.74 & 38.10 & 6.25 & 8.40 \\
Skewness & 1.24 & 1.70 & 5.36 & 1.86 & 5.70 & $(3.80)$ \\
Kurtosis & 2.54 & 7.07 & 41.91 & 5.71 & 43.21 & 31.58 \\
Observations & 199 & 199 & 199 & 199 & 199 & 199 \\
\hline
\end{tabular}

\subsection{Statistical analysis}

Reduced Form Equations

In order to trigger the statistical analysis, obtaining fitted values of the reduced form equations was necessary. Various combinations of variables for the endogenous variables were tested and the summary results are given in Table 3.

Table 3: Results of Endogenous Variables

\begin{tabular}{|c|c|c|c|}
\hline Variables & $\begin{array}{c}\text { Return on } \\
\text { Assets }\end{array}$ & Market Power & NPA \\
\hline Constant & $\begin{array}{l}2.2994 * \\
(1.1031)\end{array}$ & $\begin{array}{l}-1.5782 \\
(2.7690)\end{array}$ & $\begin{array}{l}3.9816^{*} \\
(1.7399)\end{array}$ \\
\hline Interest Rate & $\begin{array}{l}0.341)^{*} \\
(0.0428)\end{array}$ & $\begin{array}{l}0.1378^{*} \\
(0.0693)\end{array}$ & $\begin{array}{l}-0.1242 * \\
(0.0578)\end{array}$ \\
\hline Cost of Funds & $\begin{array}{l}-0.4541 * \\
(0.0862)\end{array}$ & & \\
\hline Operating Expenses & $\begin{array}{l}-0.2687^{*} \\
(0.0862)\end{array}$ & & $\begin{array}{l}0.2126^{*} \\
(0.0614)\end{array}$ \\
\hline NPA & $\begin{array}{c}-0.4045^{*} \\
(0.0451)\end{array}$ & & \\
\hline Outreach & & $\begin{array}{l}0.1342^{*} \\
(1.5782)\end{array}$ & $\begin{array}{c}0.0528^{*} \\
(0.0253)\end{array}$ \\
\hline Market Power & & & $\begin{array}{c}-0.2282^{*} \\
(0.0511)\end{array}$ \\
\hline R-squared & $51.57 \%$ & $8.30 \%$ & $11.65 \%$ \\
\hline Durbin-Watson & 1.2321 & 0.6982 & 1.3109 \\
\hline
\end{tabular}




\section{Return on assets}

ROA $=2.2994+0.3419 *$ Interest Rate $-0.4540 *$ Cost of Funds $-0.2687 *$ Operational

Expenses - 0.4044*Non-Performing Accommodations

It is evident that when interest rates increase and cost of funds decreases, the net interest margin of institutions will increase. Thereby, the profitability of the institutions increases. This coincides with the views of Sanderatne (2007) on interest income being the main source of income of an MFI and that profitability depends on interest rates.

When operating expenses increase, the return on assets decreases, as the cost of the company increases, deteriorating the income/return of such an institution. This is similar to the views of Dissanayake (2012), who states that there is a negative relationship between profitability and operational expenses.

Furthermore, when non-performing accommodations increase, the return from loans, which is the main income source of an MFI, decreases as the borrowers refrain from honoring obtained loans. Thereby, the return on assets decreases. These factors conform to the analyses done by Sanderatne (2007), and Cotler and Almazan (2013).

Outreach was also assumed to be a factor which determines profitability. However, outreach proved to be insignificant in this analysis. This could be because MFIs are dispersed beyond the number of branches as service centres, collection centres etc. Further, employees visit door-to-door in order to provide services. Therefore, the number of branches was irrelevant in deciding profitability in this sample.

\section{Average loan size}

Even though, average loan size was expected to be determined by interest rates similar to Cotler and Almazon (2013), this was not observed in the sample considered. Therefore, the endogenous assumption made did not materialize, and the fitted value of average loan size was not required to proceed with the analysis. It can be assumed that the average loan size is mainly decided by the requirements of the borrowers and not necessarily based on the interest rates or profitability goals of a particular MFI.

\section{Market power}

Market power $=-1.5782+0.1378 *$ Interest Rates $+0.1342 *$ Outreach

The observation that when interest rates increase, the market power increases is peculiar because when interest rates increase the number of borrowers attracted to such institutions should reduce. Nevertheless, this indicates that microfinance borrowers may not have the financial literacy to assess the interest rates offered by companies and choose the lowest interest rate. Further, there are many ways in which an MFI could camouflage the high interest rates they charge from borrowers. Quoting daily, weekly and monthly rates where 
the borrower does not know how to annualize and get the actual interest rates is commonly done by MFIs. Further, quoting the installment instead of the interest rate also makes it difficult for the borrower to identify the actual interest rate. Therefore, when interest rates are high, MFIs may use such gains to advertise and market their products and increase their market power. This increase in market power is possible as the clients are ignorant of the interest rates.

As expected, when the outreach is increased by increasing the number of branches the number of borrowers increases inevitably. Therefore, market power will increase.

\section{Non-performing accommodations \\ Non-performing Accommodations $=3.9817-0.1242 *$ Interest Rates + \\ $0.2126 *$ Operational Expenses $-0.2282 *$ Market Power $+0.0528 *$ Outreach}

When interest rates increase the expectation was that non-performing accommodations would increase. However, the results indicate otherwise. This could be linked to the irresponsible lending practices of MFIs in Sri Lanka. When interest rates are high the installments that need to be repaid are high, resulting in the inability of a borrower to honor the payment on time. MFIs in Sri Lanka tend to lend to clients to repay another loan (evergreening of loans). Due to this practice non-performing accommodations may go down. Thus, when interest rates go up, the borrower will tend to borrow from other financial institutions to repay the loan, which may reduce non-performing accommodations. Due to this scenario the actual impact of interest rates on non-performing accommodations is distorted.

When operational expenses and outreach increase, the number of loans granted may increase and the rate of default may increase. Therefore, non-performing accommodations may increase. Further, when market power increases, the influence an MFI has on a borrower is higher, which will lead to stringent recovery action. Therefore, as expected, non-performing accommodations will decrease.

\section{Determinants of interest rates}

Out of the numerous combinations tested with independent variables and fitted values of the endogenous variables, a summary of the five models used for the analysis is given in Table 4. Model 1-5 - Regression models with various combinations of the variables considered were analyzed to identify the best fitting model. Model 5 indicated the highest number of variables being significant. This model also resulted in the highest $\mathrm{R}^{2}$. Therefore, it is the most feasible model, and can be presented as follows:

Interest Rate $=-10.9185+0.2353 *$ Interest Rate $(-1)+0.8835^{*}$ Cost of Funds + $0.6564 *$ Operating expenses $+0.7942 *$ Return on Assets $+0.6875 * \ln$ Total Assets 
Table 4: Combinations for the Analysis on Determinants of Interest Rates

\begin{tabular}{|c|c|c|c|c|c|}
\hline Variables & Model 1 & Model 2 & Model 3 & Model 4 & Model 5 \\
\hline \multirow[t]{2}{*}{ Constant } & $10.7005^{*}$ & $11.2157^{*}$ & 2.6258 & $11.6103^{*}$ & $-10.9185^{*}$ \\
\hline & (3.1284) & $(8.6963)$ & $(1.2679)$ & $(1.4679)$ & $(5.1059)$ \\
\hline \multirow{2}{*}{ Lag of Interest Rates } & - & $0.3893^{*}$ & $0.2440 *$ & $0.4034 *$ & $0.2353^{*}$ \\
\hline & - & $(0.0459)$ & $(0.0379)$ & $(0.0480)$ & $(0.0364)$ \\
\hline \multirow[t]{2}{*}{ Cost of Funds } & $1.2189 *$ & $1.0684^{*}$ & $0.8911^{*}$ & $1.0356^{*}$ & $0.8835^{*}$ \\
\hline & $(0.1551)$ & $(0.1108)$ & $(0.0872)$ & $(0.1153)$ & $(0.0801)$ \\
\hline \multirow[t]{2}{*}{ Operating Expenses } & - & - & $0.6288^{*}$ & - & $0.6564^{*}$ \\
\hline & - & - & $(0.0466)$ & - & $(0.0458)$ \\
\hline Non-Performing & $0.9732 *$ & $0.4724^{*}$ & - & - & - \\
\hline Accommodations & $(0.2779)$ & $(0.1694)$ & - & - & - \\
\hline \multirow[t]{2}{*}{ Average Loan Size } & & & & 0.0000 & - \\
\hline & & & & $(0.0000)$ & - \\
\hline \multirow[t]{2}{*}{ Market Power } & 0.2371 & - & - & - & - \\
\hline & $(0.1602)$ & - & - & - & - \\
\hline \multirow[t]{2}{*}{ Return on Assets } & $0.4421 *$ & $0.4265^{*}$ & $0.8014 *$ & 0.2013 & $0.7942 *$ \\
\hline & $(0.1848)$ & $(0.1411)$ & (0.1016) & $(0.1217)$ & $(0.0969)$ \\
\hline \multirow[t]{2}{*}{ Experience } & 0.0912 & - & - & - & - \\
\hline & $(0.1786)$ & - & - & - & - \\
\hline \multirow[t]{2}{*}{ Total Assets } & & -0.1043 & - & - & $0.6875^{*}$ \\
\hline & & $(0.4439)$ & - & - & $(0.2441)$ \\
\hline \multirow[t]{2}{*}{ Nature } & & -2.6189 & 1.8864 & -2.9465 & - \\
\hline & & $(2.3796)$ & $(1.3185)$ & (1.6902) & - \\
\hline Adjusted R2 & $28.21 \%$ & $51.23 \%$ & $71.38 \%$ & $49.72 \%$ & $71.73 \%$ \\
\hline Durbin-Watson & 1.544 & 1.5568 & 1.2645 & 1.2122 & 1.2536 \\
\hline
\end{tabular}

$* 5 \%$ significance level

\section{Lag of interest rates}

Lag of interest rate was significant and positive in all combinations tested, indicating that when the prior year's lending interest rate is high, this year's interest rates will go up. This conforms to the expected outcome and indicates that there is a tendency to increase interest rates over time.

\section{Cost of funds}

H1 - Lending interest rates will be indifferent on cost of funds of the microfinance institution

Cost of funds has to be the main determining factor of interest rates. This is evident through this analysis, similar to Sanderatne (2007) and Cotler and Almazon (2013). Any rational entity attempts to obtain a gross profit (i.e. result after deducting the cost of sales from revenue) to become profitable. Cost of funds is synonymous with cost of sales in the context of financial institutions. Therefore, MFIs will also be conscious of their cost of funds when deciding the optimum interest rates to charge from its borrowers. Hence, when the cost of funds increases the interest rates are synonymously increased. 


\section{Efficiency}

Out of the efficiency indicators, only non-performing accommodations rate and operational expenses were significant, whereas average loan size was not significant. It was also observed that when efficiency decreases interest rates increase, similar to the studies carried out by Cotler and Almazon (2013), Fehmeen (2010), Gonzalez (2010), Sandaratne (2007).

H2 - Lending interest rates will be indifferent on Non-Performing Accommodation Rate

When non-performing accommodations increase, MFIs will not have revenue generating assets and may have to incur an expense on monitoring and recovering such accommodations, and thereby, their profitability will reduce. Therefore, such institutions may try to increase interest rates to recover their profitability covering the operational cost incurred on non-performing accommodations. When interest rates increase, the profitability is assumed to increase. Therefore, when non-performing accommodations increase there is a tendency for the interest rates to increase as well.

H3 - Lending interest rates will be indifferent on average loan size

Average loan size is set by companies based on their profitability goals and the requirements of their borrowers. Further, when the average loan size increases the cost to service the loan increases as the operational costs increase. Therefore, it was assumed that when the average loan size increases, the number of loans to service is less, leading to high profitability. Therefore, interest rates will not have to compensate for the inefficiencies of the MFI. However, this will mainly be based on the requirements of the borrower, which could be the reason for the non-dependence of interest rates on average loan size, even though Cotler and Almazon (2013) found otherwise.

H4 - Lending interest rates will be indifferent on operating expenses

Increasing operating expenses as a percentage of the loan portfolio is an indication of the operational efficiency of any entity. Therefore, like other efficiency indicators, it was assumed that when efficiency increases interest rates will decrease. This phenomenon is observed with regard to operational expenses as well. When operational expenses as a percentage of the total loan portfolio increases, the interest rate increases in order to cover the costs. This complements the studies carried out by Cotler and Almazon (2013), Fehmeen (2010), Rosenburg et al. (2009) and Gonzales (2010).

\section{Competition}

H5 - Lending interest rates will be indifferent on competition

When competition increases the interest, rates have to go down in order to attract borrowers from other microfinance service providers. Hudon (2007) has identified competition as a main factor that determines interest rates and Cotler and Almazon (2013) have found that 
when competition increases interest rates go down in Asian contexts. Fehmeen (2010), Peterson and Rajan (1995), Boot and Thakur (2000), and Mcintosh and Wydick (2005) have also found that competition has a significant effect on interest rates.

However, this was not observed in the MFI context in Sri Lanka as the market power variable did not report any significant results. Further, the analysis on whether competition is dependent on interest rates also did not give results as expected. Therefore, it is evident that competition does not have a positive effect to reduce interest rates as expected. This could be mainly due to the camouflaging of actual interest offered by MFIs. Therefore, the expected effectiveness from competition is not achieved.

\section{Company characteristics}

H6 - Lending interest rates will be indifferent on the experience of the microfinance institution

It was presumed that the experience of an MFI has an effect on its interest rates. When the experience of a firm is high it will be able to reduce its interest rates. Nevertheless, this could be the other way round too, because if the experience of a firm is high, their bargaining power increases against the borrowers, which may enable them to charge higher interest rates. However, such effects were not identified in the considered sample.

H7 - Lending interest rates will be indifferent on profitability

Profitability and interest rates of a firm go hand in hand. When return on assets, which is the profitability indicator considered in this study, increases, the interest rates increase. This result was as expected. When profitability increases an MFI will want to increase it even further by increasing its lending interest rates.

H8 - Lending interest rates will be indifferent on the size of the microfinance institution

As presumed, when the size of the microfinance institution increases, its lending interest rates increase. When the microfinance institution is large, it indicates that the institution is well established and sustainable. Therefore, their bargaining power is high and they need not take additional effort to reduce their interest rates to attract borrowers. Therefore, the interest rates may increase when the size of the firm increases.

H9 - Lending interest rates will be indifferent on nature of microfinance institution

The MFIs considered here were finance companies and institutions that are not finance companies. This is also the segregation of regulated MFIs and non-regulated MFIs. Hence, it was expected to test whether there is a difference in the way regulated and non-regulated entities set the interest rates. The ideal situation is that regulated entities should charge lower interest rates. This is because they have access to low cost funding sources such as deposits 
and low cost borrowings through recognition as a regulated entity, compared to nonregulated entities. Further, regulators are continuously monitoring the practices and procedures carried out by MFIs, which will be for the benefit of the clients of such institutions. Therefore, interest rates have to be lower for finance companies compared to other non-regulated companies. However, as the nature of the MFIs variable is insignificant, this expectation has not been achieved in the Sri Lankan context. This may be due to the cost of compliance these entities incur.

\section{Conclusion}

The lending interest rates of MFIs in Sri Lanka are considerably high. This deprives the lowincome earning segment of the country access to finance, which is against the main objectives of microfinance. Therefore, high interest rates may result in persons with low income remaining within the 'cycle of poverty'. However, previous research indicates that microfinance borrowers are willing to pay and can afford a comparatively higher interest rate than bank borrowers. Further, considering the risks MFIs face and the higher administration and operational costs MFIs incur, charging a higher interest rate can be justified from the point of view of the sustainability of MFIs. However, it is important to attempt to control and reduce interest rates to an acceptable level, with a view of meeting the social objective of microfinance. Thus, identifying the determinants of microfinance interest rate was of importance.

The study revealed that the prior period's interest rate, cost of funds, non-performing accommodations, operating expenses, return on assets and natural log of total assets of the MFIs increase interest rates. Therefore, main determinants of interest rates where policy decisions can be taken are the cost of funds, efficiency, profitability and size of the institution. Nevertheless, competition, nature and experience of MFIs, which can be expected to contribute as positive factors to reduce interest rates did not show as significant in the study.

\subsection{Policy recommendations}

Mainly there are two methods to reduce the interest rates of MFIs, without subsidizing, which are practiced in other countries: imposing an interest rate ceiling and controlling the determinants of interest rates.

\section{Imposing an interest rate ceiling}

The most apparent answer to curtail interest rates is imposing a ceiling on interest rates. The ceiling could be either imposed directly for lending interest rates or a ceiling for interest margin, which will control both lending interest rates and costs of funds. The Reserve Bank of India (RBI) has been practicing a cap on the interest rate margin. Even so, whether this ceiling has helped to control the lending interest rates as expected is questionable. In the RBI 
context, the interest margin cap is imposed based on the size of the entity and the loan rate will be the cost of funds plus the margin (RBI 2014).

However, according to Porteous and Helms (2005), this step comes with a negative effect of microfinance lenders being reluctant to grant loans to low income persons, resulting in limited access to credit for them. Therefore, Porteous and Helms (2005) is of the view that it is best to let the interest rates be determined by market forces. Further, if a ceiling is set, even the MFIs that charge lower interest rates will be forced to move towards a higher rate.

\section{Controlling the determinants of interest rates \\ Cost of Funds}

Cost of funds can be reduced by encouraging entities to come within the regulatory purview and have access to low cost funding sources such as deposits and borrowings. Another method is to impose a ceiling on the cost of sources of funds. At present, the Licensed Finance Companies in Sri Lanka are operating subject to an interest rate ceiling on public deposits, which is linked to Treasury Bill rates.

\section{Efficiency}

All MFIs should be encouraged to identify and eliminate unnecessary operational costs, which reduce their profits and also to reduce the costs to an optimal level. This is especially important in relation to MFIs which receive donor funds, which makes them follow a relaxed approach on operational and administrative costs.

\section{Competition}

Even though, competition was not significant in the results of this study, it is one of the main tools used to reduce interest rates. The number of microfinance service providers may not reflect the level of effective competition in the Sri Lankan context. Microfinance clients may be unable to make a proper differentiation between microfinance service providers due to weak transparency. Further, the large number of institutions have led to overindebtedness of the sector. Firstly, the terms and conditions imposed by MFIs should be made comparable and easily understandable to the clientele of microfinance. Porteous and Helms (2005) state that if disclosures on interest rates are appropriately made and information is widely available, enabling comparison between entities, it will stimulate price competition, enabling lower interest rates.

Secondly, the public should be made aware of their right to obtain information regarding loan products, understand terms and conditions, and such conditions should be available in their preferred language. The importance of transparency of the pricing policy was highlighted as a policy recommendation by Hudon (2007). Further, financial education and literacy levels have to be improved in order to enable borrowers to compare and understand the product that offers them the lowest interest rates. Therefore, improving transparency will lead to determination of interest rates through market forces. 


\section{Characteristics of the MFI}

\section{Experience, size and profitability}

Policies to increase size and profitability of an MFI will not produce good results as indicated in the study. Until competition is increased through transparency, experienced and stable firms which perform well in the market will continue to charge higher interest rates from their borrowers, without passing the benefits to them by reducing interest rates.

\section{Nature of MFI}

Regulatory attention needs to be given to the result of this variable. The regulated entities should logically be setting lower interest rates compared to un-regulated entities. Despite this fact, this variable did not give any significant results in this study. Therefore, regulators of finance companies should be more considerate on the interest rates such companies offer.

\subsection{Limitations}

This study only considers the factors in relation to MFIs. The borrowers' perspective in relation to interest rates charged by MFIs was not taken into consideration. As Fehmeen (2010), who has considered the financial literacy level of the microfinance borrowers, states, factors specific to the borrowers of MFIs that may influence interest rates must be considered in future research. Further, replicating this study after the regulatory framework introduced by the Microfinance Act, No. 6 of 2016 is implemented through licensing and registering of MFIs, will also add value to the research, by enabling comparison of regulated entities and unregulated entities. Keeping in mind the above mentioned limitations, this study attempts to initiate research on microfinance interest rates of Sri Lanka, which lacks updated research. Further, in-depth research in this area will add more value to effective policy formulation in the microfinance regulatory arena. 


\section{References}

Boot, Arnoud WA, and Anjan V. Thakor. "Can relationship banking survive competition?" The journal of Finance 55.2 (2000): 679-713.

Carbo-Valverde, Santiago, Francisco Rodriguez-Fernandez, and Gregory F. Udell. "Bank market power and SME financing constraints." Review of Finance 13.2 (2009): 309-340.

CGAP, [Online] "What is Financial Microfinance? How does it relate to Financial Inclusion?" Available from: http://www.cgap.org/about/faq/what-microfinancehow-does-it-relate-financial-inclusion-0. [Accessed 11 May 2017], 2017

Duval, Ann. "The impact of interest rate ceilings on microfinance." CGAP Donor Brief No 18 (2004).

Claeys, Sophie, and Rudi Vander Vennet. "Determinants of bank interest margins in Central and Eastern Europe: A comparison with the West." Economic Systems 32.2 (2008): 197-216.

Cotler, Pablo, and DeyaniraAlmazan. "The lending interest rates in the microfinance sector: searching for its determinants." (2013).

Cull, Robert, AsliAsliDemirgüç-Kunt, and Jonathan Morduch. "Microfinance meets the market." Journal of Economic perspectives 23.1 (2009): 167-92.

Dissanayake, D. M. N. S. W. "The determinants of return on equity: evidences from Sri Lankan microfinance institutions." (2012).

Fehmeen, [Online] 10 Determinants of Interest Rates in Microfinance, Available from: http://creationinvestments. com/news/10-determinants -of-interest -rates -inmicrofinance/. [Accessed 10 May 2017], 2010

Fernando, Nimal A. "Understanding and dealing with high interest rates on microcredit: A note to policy makers in the Asia and Pacific region." (2006).

Gonzalez, Adrian, and Richard Rosenberg. "The State of Microfinance-Outreach, Profitability, and Poverty." Washington, DC: Consultative Group to Assist the Poor (CGAP Working Paper) (2006).

Gonzalez, Adrian. "Analyzing microcredit interest rates: A review of the methodology proposed by Mohammed Yunus." (2010).

Hudon, Marek. "Fair interest rates when lending to the poor." (2007).

Kipesha, Erasmus Fabian, and Xianzhi Zhang. "Sustainability, profitability and outreach tradeoffs: evidences from microfinance institutions in East Africa." European Journal of Business and Management 5.8 (2013). 
Maimbo, Samuel Munzele, and Claudia Alejandra Henriquez Gallegos. Interest rate caps around the world: still popular, but a blunt instrument. The World Bank, 2014.

Marquez, Robert. "Competition, adverse selection, and information dispersion in the banking industry." The Review of Financial Studies 15.3 (2002): 901-926.

McIntosh, Craig, and Bruce Wydick. "Competition and microfinance." Journal of development economics 78.2 (2005): 271-298.

News.LK.,[Online] “A cap on the Interest Rate on Micro Finance Lending”, Available from: https://www.news.lk/news/world/item/5986-a-cap-on-the-interest-rates-onmicro-finance-lending. [Accessed 08 May 2017], 2015

Petersen, Mitchell A., and Raghuram G. Rajan. "The effect of credit market competition on lending relationships." The Quarterly Journal of Economics 110.2 (1995): 407-443.

Porteous, David, and Brigit Helms. "Protecting microfinance borrowers." (2005).

Reserve Bank of India, Non-Banking Financial Company - Microfinance Institution Directions

Roberts, Peter W. "The profit orientation of microfinance institutions and effective interest rates." World Development 41 (2013): 120-131.

Rosenberg, Richard. 2002. "Microfinance Interest Rates.” Occasional Paper, CGAP, 2014

Rosenberg, Richard, Adrian Gonzalez, and SushmaNarain. "The new moneylenders: are the poor being exploited by high microcredit interest rates?." Moving beyond storytelling: Emerging research in microfinance. Emerald Group Publishing Limited, 2009. 145-181.

Sanderatne, Nimal.[Online] "Financial Viability and sustainability of Microfinance: The Financial System Approach. Association of Professional Bankers, Sri Lanka, 19th Anniversary Convention." Available from: http://www. apbsrilanka.org/ articles/ 19_ann_2007 / 1_Dr.\%20Nimal\%20Sandaratne.pdf. [Accessed 12 June 2017], 2007

Schicks, Jessica. "Microfinance Over-Indebtedness: Understanding its drivers and challenging the common myths." Centre Emile Bernheim (CEB) Working Paper 10 (2010): 047.

The Sunday Times, "Microfinance Blamed for Rising Indebtedness in North", Sunday, October 15, 2017

Zerai, Bereket, and Lalitha Rani. "Is there a tradeoff between outreach and sustainability of micro finance institutions? Evidence from Indian microfinance institutions (MFIs)." European Journal of Business and Management 4.2 (2012): 90-98 


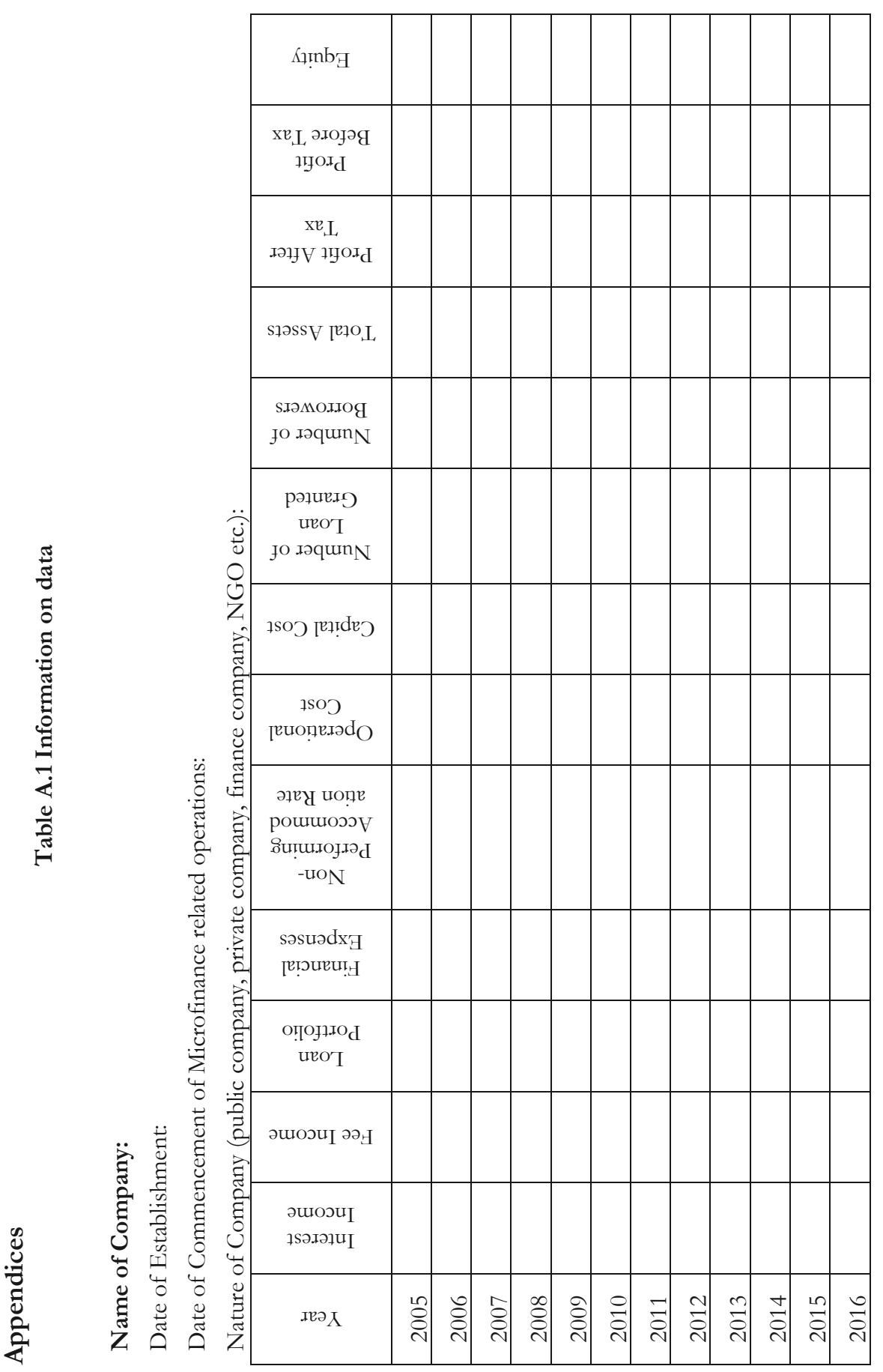

